\title{
COVID-19 and the right to education in Chile: An opportunity to revisit our social contract
}

\author{
Denisse Gelber ${ }^{1}\left[\right.$ Carolina Castillo $^{1}$ (1) - Luciano Alarcón ${ }^{2} \cdot$ Ernesto Treviño $^{1}$ (i) \\ Rosario Escribano ${ }^{1}$ (1)
}

Accepted: 2 February 2021 / Published online: 22 February 2021

(c) UNESCO Institute for Lifelong Learning and Springer Nature B.V. 2021

\begin{abstract}
The COVID-19 pandemic is pushing the world into a devastating economic and social scenario. The consequences of this crisis largely impact children and teen agers, both now and in the future. School closures have particularly affected vulnerable children, deepening the effects of their unequal socio-economic circumstances. In this context, the actions governments are taking to protect their citizens' right to education will be crucial to reducing or exacerbating inequality in the long term. The authors of this article analyse the case of Chile, one of the most successful countries in Latin America regarding educational achievement and enrolment, as well as the most segregated educational system among member countries of the Organisation for Economic Co-operation and Development (OECD). How is the right to education being guaranteed for all during the COVID-19 pandemic? Are the measures taken by the Ministry of Education mitigating or intensifying long-term inequalities? Based on the 4-A scheme described by Katarina Tomasevski, which conceptualises national governments' obligations to guarantee the right to education, the authors examine the normative basis of Chile's market-oriented educational system (1980-2013) as well as the latest educational reform (2014-2017), which aimed to promote the right to quality education, and critically analyse the measures adopted by the Chilean Ministry of Education in response to the pandemic. The authors conclude that Chile is facing a major challenge to ensure the right to education for all. A new social contract is required to reduce structural inequalities, and to avoid a potential setback in human rights.
\end{abstract}

Keywords Human right · Education · COVID-19 · Inequality · Chile

\section{Résumé}

La COVID-19 et le droit à l'éducation au Chili : l'occasion de revisiter notre contrat social - La pandémie de COVID 19 entraîne le monde vers un scénario économique et

Denisse Gelber

denisse.gelber@gmail.com

Extended author information available on the last page of the article 
social dévastateur. Les conséquences de cette crise impactent fortement le présent et l'avenir des enfants et des adolescents. Les fermetures d'écoles ont particulièrement affecté les enfants en aggravant les effets des inégalités socio-économiques. Dans ce contexte, les mesures que prennent les gouvernements pour protéger le droit des citoyens à l'éducation seront capitales en ce qui concerne la réduction ou l'aggravation des inégalités à long terme. Les auteurs de cet article analysent le cas du Chili, l'un des pays latino-américains qui connaissent le plus de succès en matière de réussite scolaire et de scolarisation, et dont le système éducatif est en même temps le plus ségrégatif de tous les pays membres de l'Organisation de coopération et de développement économiques (OCDE). Comment le droit à l'éducation pour tous y est-il garanti pendant la pandémie de COVID-19 ? Les mesures prises par le ministère de l'Éducation atténuent-elles à long terme les inégalités ou les creusent-elles ? Les auteurs s'appuient sur le schéma des 4 A (selon lequel l'éducation doit être abordable, accessible, acceptable et adaptable - n.d.l.t.), dans lequel Katarina Tomasevski conceptualise les obligations des gouvernements de garantir le droit à l'éducation. Ils l'utilisent non seulement pour examiner la base normative du système chilien de l'éducation axé sur le marché (1980-2013) et la dernière réforme de l'éducation (2014-2017) visant à promouvoir le droit à une éducation de qualité, mais aussi pour livrer une analyse critique des mesures adoptées par le ministère de l'Éducation chilien en réponse à la pandémie. Ils concluent que pour garantir le droit à l'éducation pour tous, le Chili doit relever un défi d'importance. Un nouveau contrat social est nécessaire pour réduire les inégalités structurelles et éviter une régression potentielle des droits humains.

\section{Resumen}

COVID-19 y el derecho a la educación en Chile: Una oportunidad para revisitar nuestro contrato social - La pandemia del COVID-19 está empujando al mundo a un escenario económico y social devastador. Las consecuencias de esta crisis impactarán sobremanera a la niñez y adolescencia, tanto en el presente como en el futuro. El cierre de los establecimientos educativos ha afectado particularmente a la población vulnerable, profundizando los efectos de su desventaja socio-económica de origen. En este contexto, las acciones que tomen los Estados para proteger el derecho a la educación serán cruciales para reducir o exacerbar la inequidad en el largo plazo. Los autores de este artículo analizan el caso de Chile, uno de los países de América Latina con mayores tasas de matriculación y completitud, a pesar de contar con el sistema educativo más segregado entre los países de la Organización para la Cooperación y el Desarrollo Económicos (OCDE). ¿Cómo se está garantizando el derecho a la educación durante la pandemia del COVID-19? Las medidas tomadas por el Ministerio de Educación, ¿están mitigando o agudizando las inequidades en el largo plazo? Los autores abordan ambas preguntas en base a las 4-As definidas por Katarina Tomasevski, en que se conceptualizan las obligaciones de los Estados para garantizar el derecho a la educación. En primer lugar, examinan las normativas que sentaron las bases del sistema educativo orientado en el mercado (1980-2013) así como las modificaciones propuestas por la última reforma educativa (2014-2017), que buscaron promover el derecho a la educación de calidad. Luego, los autores analizan las 
medidas adoptadas por el Ministerio de Educación en respuesta a la pandemia. Concluyen que Chile está enfrentando un gran desafío para poder asegurar el derecho a la educación para todos. Por lo tanto, se requiere un nuevo contrato social para reducir las inequidades estructurales, y para evitar un potencial revés en materia de derechos humanos.

\section{Introduction}

The COVID-19 pandemic is pushing the world into a devastating scenario. The global economy is facing the deepest recession since the Great Depression (World Bank 2020), and chances of economic recovery are uncertain, likely to worsen with every additional wave of infection (OECD 2020). ${ }^{1}$ Recent studies estimate that the sanitary crisis will be accompanied by increases in unemployment (CEPAL-OIT 2020; ILO 2020) and poverty rates, especially in developing countries (CEPAL 2020), and consequent retrogression in human development (UNDP 2020).

Despite low COVID-19 mortality rates among children, several reports estimate they will suffer the most due to social and economic effects of the pandemic, including hunger, domestic violence, school dropout (Sanz et al. 2020), child labour (ILO and ECLAC 2020; ILO and UNICEF 2020) and preventive diseases with an increasing rate of child mortality (UN 2020). Moreover, school closures are mainly affecting vulnerable children unable to access formal education, meals, vaccines, emotional support, and shelter. In this scenario, the actions governments are taking to protect their citizens' right to education are crucial, since they may reduce or exacerbate losses in the long term (Reimers and Schleicher 2020a, 2020b).

From a human rights perspective, governments have to respect (by avoiding any action that might deny access to school), protect (by eliminating cultural barriers and violence in schools) and fulfil the right to education (by making it available for everybody) (UNICEF 2007). While several international treaties describe governmental obligations, the most comprehensive mechanism is the 4-A scheme conceptualised by the United Nations Committee on Economic, Social and Cultural Rights (CESCR 1999). ${ }^{2}$

In her Manual on rights-based education, human rights specialist Katarina Tomasevski (2004) labels the scheme "4-A" because it is based on four essential and interrelated features of education. The first two, availability and accessibility, were included in Article 13(2) of the International covenant on economic, social and cultural rights. (ICESCR) adopted by the United Nations in 1966 (UN 1966). In 1999, Articles 13 and 14 of the Covenant, both concerning the right to education, were elaborated with "general remarks", including the other two features,

\footnotetext{
1 This article was drafted in August 2020. Therefore, we consider all the measures applied by the Chilean Ministry of Education between March and July of 2020. It is important to mention that the vast majority of schools (more than 90\%) remained closed throughout the entire school year.

2 The 4-A scheme is considered in rulings by the Inter-American Court of Human Rights on cases regarding discrimination in the educational system (IACHR 2020a).
} 
acceptability and adaptability (CESCR 1999, pp. 2-3). First, education should be available. Governments should ensure educational provision from early childhood education onwards, with adequate infrastructure, amenities, information and communications technology (ICT), libraries, trained and well-paid teachers. Also, governments should not interfere with private sector initiatives and academic freedom, as long as they meet the national standards of education (UNESCO 2019). Second, education should be accessible. An educational system cannot discriminate by ethnicity, religion, socio-economic background, or gender. Moreover, education should be economically and geographically accessible (free at primary level and progressively free in secondary and tertiary education). Third, education should be acceptable. Governments should provide quality education, fulfilling the aims of education defined in international treaties, to ensure that every child has an equal chance to develop her or his full potential, providing pertinent and culturally adequate contents. Therefore, parents are entitled to choose an education for their children based on religious or moral beliefs, while minorities are free to create their own schools. Finally, in accordance with the key principle of children's rights, education should be adaptable to the specific needs of each student, providing the assistance they require to promote their best interests (Tomasevski 2004).

Based on the 4-A scheme, our study analyses the case of Chile, one of the most successful countries in the region regarding educational achievement, universal enrolment and attainment (Gelber et al 2016; OECD 2016), but also one of the most segregated and unequal educational systems among member countries of the Organisation for Economic Co-operation and Development (OECD) (UNDP 2017), where educational attainment is primarily determined by household income (OECD 2010). The questions guiding our study were:

- How is the right to education being guaranteed for all during the COVID-19 pandemic?

- Are the measures taken by the Ministry of Education mitigating or exacerbating long-term inequalities?

To answer these questions, we examined the normative basis of Chile's marketoriented educational system (1980-2013), as well as the latest educational reform (2014-2017), and the measures adopted by the Chilean Ministry of Education in response to the pandemic.

Our methodological approach included the identification, collection and systematisation of all the national laws that set the basis for the market-oriented educational system, such as the National Constitution (GoC 1980), and other laws and decrees; furthermore, we considered the norms defined by the latest structural educational reform (GoC 2015a, 2016a, 2017), as well as the measures adopted by the Ministry of Education in response to the sanitary crisis caused by the COVID-19 pandemic. To analyse and interpret the data, we applied a categorical thematic analysis 
(Strauss and Corbin 2002), ${ }^{3}$ we critically analysed each of these categories and contrasted them with the 4-A scheme (UNESCO 2019).

We begin by introducing the case of Chile, describing the legislative origins of the Chilean market-oriented educational system and evidencing the segregation and inequality it produced. Second, we analyse how the latest educational reform (2014-2017) aimed to promote the right to education for all, in terms of the 4-A scheme. Next, we critically analyse the measures implemented by the Chilean Ministry of Education during the first five months (March-July 2020) of the COVID19 pandemic, and we assess the remaining challenges to guaranteeing delivery on the right to education for all. Finally, we present concluding remarks and recommendations.

\section{Context: a market-oriented educational system which reproduces inequality}

During the 1980s, the dictatorship of Augusto Pinochet initiated a neoliberal reform in Chile that dismantled public services, not only through several legislations but mainly by implementing a new Constitution (GoC 1980), which is still in effect. It was during this period that the basis for a subsidiary state and a market-oriented educational system was set (Torche 2005). First, the governance of public schools was decentralised to municipalities, which, instead of ensuring minimal resources or quality, left educational supply reliant on the unequal resources municipalities obtained from local revenues in a highly segregated territory (Flores 2008). Second, private and independent actors were authorised to easily open and manage a new type of school, privately owned but subsidised by the Chilean government. Third, vouchers were introduced to finance every public and private-subsidised school, based on enrolment and attendance (Bellei 2015). By the end of the 1980s, the competition between these schools not only increased but also became unfair. In 1988, the Ministry of Education started implementing the Educational Quality Measurement System (SIMCE) to gather information on students' academic performance at the national level, and publicly release schools' performance to inform parents on their school choice (Falabella and Ramos Zinche 2019). A hefty competition between schools was generated not only for resources, which were dependent on enrolment, but also for efficiency, measured with SIMCE results. Even though private government-subsidised schools had comparative advantages, the government provided the same resources for them as for public schools regarding school texts, infrastructure resources and technical support.

On the one hand, schools were allowed to select students (e.g., based on previous academic performance, religious background, family income) without transparent and public admission criteria. On the other hand, private-subsidised schools were authorised to charge an extra monthly fee from families at every educational level, as

\footnotetext{
${ }^{3}$ Categorical thematic analysis is used to identify categories through a rigorous and systematic coding process.
} 
well as receive private donations (Law 18.768, GoC 1988). The government did not control the use of these funds until 2011 (Law 20.529, GoC 2011). By 2013, only daytime municipal high schools were allowed to charge extra fees (i.e. co-payment), subject to several restrictions (Law 19.247, GoC 1993). To make matters worse, private school owners were able to profit from public funds (in 2016, $52 \%$ private-subsidised schools were for-profit), while municipal schools were barely able to keep up with their operational costs (Holz and Castro Paredes 2014; Treviño 2018).

These unequal conditions promoted a highly segregated educational system, even more pronounced than socio-economic segregation among households (Valenzuela et al. 2014). The number of municipal schools was reduced by half ( $80 \%$ in the 1980s and 37\% in 2015) (Falabella 2015), teaching only one-third of the national student body, while private-subsidised schools increased to $50 \%$, covering $60 \%$ of the national enrolment by 2014 (Treviño 2018). The high costs of co-payment, the restrictive admission criteria of private-subsidised schools, as well as the lack of supply of quality municipal schools in vulnerable areas, led to a concentration of vulnerable students in municipal schools and a massive exit of low-income high-performing students to the private-subsidised sector (Bellei 2013; Carrasco et al. 2017; Flores and Carrasco 2016). By 2013, $70 \%$ of students attending private-subsidised schools were required to pay extra fees (co-payment) compared to $17.3 \%$ of the students who attended municipal schools (Holz and Castro Paredes 2014).

Moreover, arbitrary selection already began in the early stages of students' trajectories. For pre-kindergarten and first grade admissions (primary school), 54\% of private-subsidised schools selected students based on their previous academic performance, and $71 \%$ schools considered family income, compared to $32 \%$ and $41 \%$ respectively of municipal schools (Godoy et al. 2014). Even though evidence has shown that co-payment does not contribute to better academic results (Elacqua et al. 2011, 2013; Mizala and Torche 2012), the educational system is divided into three realities based on students' socio-economic level and the type of school they attend (ACE 2019; Treviño et al 2018). Results from the OECD's Programme for International Student Assessment (PISA) show that Chilean students from municipal schools perform as low as students from Thailand, students from private-subsidised schools perform just as well as Mexican students and students from non-subsidised private schools (which represent $9 \%$ of enrolment) perform on the same level as students from Finland (Rosas and Santa Cruz 2013).

To make matters worse, teachers are also segregated by school sector and area. While the most prepared teachers work in urban areas and private schools, the least trained teachers work in municipal schools (MINEDUC 2019). The segregation of human and economic resources by type of school is also reflected in students' differential academic trajectories (Larrañaga et al. 2014). While retention and dropout are more common in municipal schools (MINEDUC 2018a), students from municipal schools achieve lower scores in the university admission test (PSU), even worse in municipalities with low economic resources (DEMRE 2018; UNDP 2017; Quiroz Reyes 2020) and, therefore, have lower chances of being admitted to certified higher education institutions (Contreras et al. 2007).

After a massive student movement in 2006 against inequality and the privatisation of the educational system (Donoso 2016), legislative changes began. The most 
relevant of these changes was the substitution of the Organic Law of Education (Law 18.962, GoC 1990), inherited from the dictatorship, with the General Law of Education (Law 20.370, GoC 2009) which, among other aspects, regulated the ownership and management of private-subsidised schools for the first time. First, it increased the regulations to open private-subsidised schools. Second, the selection of students by public and private-subsidised schools was forbidden in primary education, even though schools maintained this practice (Carrasco et al. 2015). Third, in 2008, the Preferential Voucher Law (Law 20.248, GoC 2008) changed the value of the voucher in two ways. First, it established an increase of nearly one third in the individual value of the voucher for students with low socio-economic status (priority students). Second, the law provided resources to schools based on their concentration level of priority students. In 2011, the Quality Assurance System (SAC) was created to define and supervise learning and achievement standards, schools' and students' progress annually (with standardised tests in maths and reading), provide guidance for schools to improve their results, as well as rank schools based on their results (Law 20.529, GoC 2011). These laws established the current highstakes accountability system, which requires schools to prepare an improvement plan aimed towards increasing average school performance, and after repeated low scores, schools can be closed (Treviño et al. 2019, 2020).

The measures prompted by students' protests in 2006 were insufficient to adjust the inequalities because they did not tackle the basis of the market-oriented educational system. Therefore, a new wave of social movements erupted in 2011. Between 2014 and 2017, a structural educational reform was implemented. In the following section, we describe its main aspects and how it intended to promote the right to education for all considering the 4-A framework.

\section{The latest educational reform (2014-2017): moving towards guaranteeing the right to education for all?}

According to the Committee on Economic, Social and Cultural Rights (CESCR 1999), every "State party" (i.e. national government) must guarantee the right to education for all in four dimensions. As mentioned earlier, the 4-A scheme (Tomasevski 2004) determines that education has to be available from early childhood education onwards, with adequate infrastructure, amenities, ICTs, libraries, trained and well-paid teachers. Second, education must be accessible, guaranteeing that there are no economic barriers to accessing education and that no student is discriminated against due to their ethnicity, religion, socio-economic background, or gender, among other criteria. Third, education should be acceptable. Governments should provide quality education, ensuring that every child has an equal chance to develop her or his full potential, providing pertinent and culturally adequate contents. Fourth, education should be adaptable to the specific needs of each student, providing the assistance they require to promote their best interest.

Matching the evidence presented above against the 4-A scheme to identify which aspects required attention in order to guarantee the right to education for all, we find the following: The market-oriented and hyper-segregated educational system 
reproduced socio-economic inequality (Valenzuela 2008; Valenzuela et al. 2010). Students' academic performance and trajectory was largely defined by the type of school they could access. Therefore, education was not accessible for every student due to economic barriers (co-payment fees), arbitrary admission policies among private-subsidised schools, and the lack of supply of quality public schools in vulnerable areas. Moreover, quality teachers were not available for every student, because the most trained ones worked in private and private-subsidised schools. Third, for the same reasons, the quality of education was also segregated by school sector. Hence, public education was not necessarily acceptable. Adaptability was mainly guaranteed for students with special educational needs (SEN), ensuring not only flexibility and adjustments in curricular programmes and teaching strategies in regular and special schools (Decree 170, GoC 2010a; Decree 83, GoC 2015b; Law 20.422, GoC 2010b), but also human and material resources to achieve educational goals (DFL 2, GoC 2010c). However, special programmes for SEN students were not mandatory, so access was not universally guaranteed for SEN students.

The latest educational reform (2014-2017) took care of each of these elements, aiming to guarantee the right to education for all. In this section, we analyse how the educational reform has improved the regulation of the right to education, in three main aspects. Since its implementation is gradual and has been delayed due to several obstacles, availability of information on its effects so far is still scarce.

\section{Accessibility}

According to recent data (OECD 2019a), Chile is the OECD member country which spends the most on education (17.4\% of total government expenditure); $12 \%$ on primary and secondary levels, and $5.4 \%$ on tertiary education, while schools are mainly funded by the government ( $63 \%$ of the total budget). However, the expenditure per student is fairly low at primary and secondary level compared to other OECD member countries (USD 5,300 and USD 9,400, respectively). Moreover, early childhood education is funded by $1.2 \%$ of the Gross Domestic Product (GDP), covering $82 \%$ of the pre-primary institutions (compared to 69\% in OECD countries) (OECD 2019a).

To guarantee every student's access to schools in the compulsory levels, ${ }^{4}$ a centralised application system was designed to eliminate arbitrary selection and copayment in public and private-subsidised schools. The Educational Admission System (EAS) is an online platform where parents define their school preferences (Law 20.845, GoC 2015a). Schools are not allowed to ask for socio-economic background information, SEN tests, interviews, academic references or religious certificates to admit students. If there are available places, students are automatically assigned to their preference. If there are no available places in any of their preferred schools, an algorithm determines the best match between parental preferences and school

\footnotetext{
${ }^{4}$ Education in Chile is free and compulsory from kindergarten to the end of secondary school. Children enter primary school (grades 1-8) at age 6. Secondary level, comprises 4 years of formal education, with different orientations in the last two years (either humanities and sciences or technical-professional subjects).
} 
availability. In these cases, students with siblings in their preferred schools, as well as students whose parents work in their preferred schools, are prioritised. EAS has been gradually implemented by region and educational level. In the first and second year of its implementation, eight out of ten students were accepted into one of their top three preferences ( $82 \%$ in the first year and $79.3 \%$ in the second year), revealing a similar success rate as those experienced in comparable systems in other countries (Carrasco and Honey 2019a, b).

To eliminate economic barriers, the reform is gradually replacing co-payment with increasing government subsidies which, after a gradual implementation period, will allow free access to every public and private-subsidised school. Also, the reform eliminated profit in private-subsidised schools, making private-subsidised schools choose between becoming non-profit or private schools (without any financial support from the government). By $2017,93.9 \%$ of private-subsidised schools had become non-profit schools (Treviño 2018). ${ }^{5}$

Despite these improvements, the educational reform does not guarantee universal access to SEN students. To enrol SEN students, private-subsidised and public schools must offer the Educational Integration Programme (Programa de Integración Escolar; PIE), which is not mandatory in every school. On the contrary, schools have to apply to include this programme, but they are not required to offer it. Therefore, the pool of accessible schools for SEN students is reduced (Treviño 2018).

\section{Availability}

The educational reform also aimed to promote quality teaching. It designed a new system for teachers' professional development and recognition which (1) increased selection criteria to apply for a teaching career; (2) defined more rigorous graduation criteria; (3) established that every institution and initial training programme had to be certified by the Ministry of Education; and (4) designed a professional development track, ensuring continuous training, external evaluations accompanied by pay rises and improved teaching conditions (Law 20.903, GoC 2016a).

The installation of a new system of professional development for teachers in 2016 included both public and private-subsidised school teachers for the first time since 1981. It incorporated measures for initial teacher training, in-service training, access to free training for trainee teachers, a significant salary increase of nearly $30 \%$, and the provision of paid time for planning and evaluation.

\footnotetext{
5 This article focuses on compulsory education up to the end of secondary level, but the educational reform also took care of post-secondary and tertiary education, creating vocational institutes and public universities, and a system to ensure the quality of the educational supply at this level. For more information about the establishment of higher education institutions (HEIs) etc, see GoC (2015c, 2016b, 2018).
} 


\section{Acceptability}

To increase the quality of public education, the educational reform introduced a new governance system, which is gradually substituting municipal administration of public schools with a centralised system dependent on the Ministry of Education. Public education will be transferred from 345 municipalities to 70 Public Education Local Services (PELS) (Law 21.040, GoC 2017). These aim to guarantee the provision of public quality education nationwide for compulsory levels. The recently approved National Public Eduacation Strategy will improve the quality of education in the public system, considering enrolment, attendance, inclusion, school coexistence and curricular implementation, among other aspects (Educación2020 2020a, 2020b). Despite this improvement, the educational reform does not modify the competition between private-subsidised and public schools for students, because funding is still dependent on enrolment, and especially attendance (Treviño et al 2019). Moreover, schools maintain their competition for high-performing students because the highstakes accountability system was not altered.

Second, to ensure that parents can freely choose the school for their children (UNESCO 2019), EAS ensures that parents have the last word deciding which (voucher or public) school their children will attend. However, the first EAS evaluation reports conclude that parents have not changed their preferences, partly because structural inequalities remain (residential segregation, transportation difficulties) and parents still have to decide among the available options in their surrounding areas (Carrasco and Honey 2019b). Among low-income families, parents tend to choose schools based on proximity (Flores and Carrasco 2016; Hofflinger et al 2020). Since the educational reform does not consider increasing the supply of schools in disadvantaged areas, low-income families remain dependent on the quality of their nearby schools.

To sum up, Chile's educational reform has made legislative progress in order to ensure accessibility, availability and acceptability. However, the success of these improvements is limited due to the lack of changes in structural inequalities, and the maintenance of the basis of schools' competition for students. Moreover, students are still not at the centre of the educational process. The absence of adaptability measures in the educational reform maintains the disadvantage of vulnerable groups, especially SEN students.

\section{Measures to fulfil the right to education during COVID-19 in Chile: still far away from students' needs and context}

Due to the pandemic, the vast majority of Chilean schools remained closed during 2020. ${ }^{6}$ This implies that 3.6 million students have been trying to learn remotely (91\% enrolled in public schools), while 200,000 teachers have been trying to teach

\footnotetext{
${ }^{6}$ A reduced number of schools $(903$ out of a total of 11,574) located in specific areas with low levels of infection reopened by the end of the year (MINEDUC 2021).
} 
remotely since March. In the context of a highly segregated educational system, as demonstrated above, our particular interest lies in investigating what measures have been implemented to guarantee the right to education for all. Even though international and national agencies recommend flexible, heterogeneous and interdisciplinary responses adjusted to local and school situations (Meneses et al. 2020; Montecinos et al. 2020; Reimers and Schleicher 2020b), the Chilean Ministry of Education implemented centralised, unilateral and uniform measures for the public and private-subsidised educational system. Moreover, despite socially segregated access to and usage levels of the internet, the vast majority of the adopted mea sures were implemented online only. Below, we match the measures promoted by the government against the 4-A scheme, investigating to what extent they guarantee the right to education for all, as well as identifying the remaining challenges.

\section{Availability-}

Most of the measures implemented by the Chilean government during the first months of the COVID-19 pandemic aimed to guarantee the availability of infrastructure for remote education, through four main mechanisms: (1) technological tools (ICT scholarships from JUNAEB) $;^{7}$ (2) online platforms for every educational level (a Learning on Line website) ${ }^{8}$ and free access to Google Suite (a collection of tools and software resources), as well as several platforms for early childhooding (the Del Jardín a la Casa website, ${ }^{9}$ App Mi Jardín, IntegrApp); (3) schemes for increasing internet access (Solidary plan for connectivity; Connectivity for Education 2030); ${ }^{10}$ and (4) TV programmes (TV Educa Chile).

Second, the Ministry of Education has made pedagogical and didactic resources available not only for early childhood teaching and learning (school supplies, activity guidelines and reading materials for families living in isolated areas), but also for primary and secondary education (a digital library to download free e-books; a Learning at home plan with printed materials to study at home; a Pedagogical support plan for high-performing public high schools). ${ }^{11}$

\footnotetext{
7 Junta Nacional de Auxilio Escolar y Becas (JUNAEB) is the National School Aid and Scholarship Board. For more information, visit https://www.junaeb.cl/becas-junaeb-old?lang=en [accessed 10 January 2021].

8 The Learning on Line website is at https://www.curriculumnacional.cl/estudiantes/Ingreso [accessed 22 January 2021].

9 The Del Jardin a la Casa [from the garden to the house] website is at https://www.junji.gob.cl/deljardin-a-la-casa/ [accessed 17 January 2021].

10 The Solidary plan for connectivity (MTT 2020) was launched on 1 April 2020. It allows users struggling to pay their bills to temporarily suspend their regular telecom service charges and activate a free 60-day connectivity bundle to browse the web and access e-mails, albeit excluding the use of data-intensive activities such as video streaming and online gaming. The Connectivity for Education 2030 project (MTT-MINEDUC 2020) was launched on 17 June 2020. It fast-tracked the provision of high-speed broadband access to several thousand schools in Chile.

11 High-performing public schools are a small group of exemplary schools in terms of quality and status, all of which are located in Santiago de Chile. For more information, see Quaresma (2017).
} 
Finally, to promote quality teaching, several programmes are being offered to train teachers in distance teaching (an Action plan for tertiary education institutions; the provision of training and online seminars by the Ministry of Education's Centre for Retraining, Experimentation and Pedagogical Research [CPEIP]; ${ }^{12}$ the provision of mentorships for principals by the Education Quality Assurance Agency [ACE]), ${ }^{13}$ and also to promote collaborative teaching through the website of the Ministry of Education and its dependencies. Part of these strategies include the dissemination of successful practices in different schools, as well as providing access to online resources from different countries (Action plan for tertiary education) and guidelines for teachers to support online teaching at kindergarten, primary, secondary and tertiary levels (MINEDUC-UCE 2020a; MINEDUC-DEG 2020a, 2020b; MINEDUC 2020a; MINEDUC-SdES 2020).

\section{Accessibility}

The measures mentioned above are mostly digital. However, not every student or teacher has adequate access to the internet, digital equipment, and few have competent digital skills. Therefore, the measures listed above are not accessible to all. The first hurdle is unequal access to digital equipment. According to the latest nationally representative household survey (CASEN 2017), 65.19\% of impoverished persons and $65.3 \%$ of individuals living in rural areas do not have a computer in their households. Moreover, almost half of the students in Chile $(45.7 \%)$ do not have digital equipment in their homes nor internet connection, and those who do have internet can only access it through their phones (Educación2020 2020a)

Second, households' structural conditions also affect accessibility. In Chile, access and use of the internet and ICTs are largely determined by income level, age, area of residence, and educational level (León and Meza 2018). Furthermore, while $41 \%$ of individuals who did not complete primary education do not use the internet, the proportion of individuals with graduate studies who do not use the internet is less than 2\% (CASEN 2017). Moreover, students who can only access printed materials require guidance or support from an adult to complete their tasks. Considering that almost $20 \%$ of Chilean households are single-parent families, a large number of students may not be able to rely on this support.

Third, inequality is reflected in digital skills. Chile presents a higher level of inequality in internet use than the OECD average, and it is one of the countries with the lowest level of digital skills and education in the group (OECD 2019b). According to the Digital Readiness Index (Yoo et al. 2018), a holistic approach which

\footnotetext{
12 The Centro de Perfeccionamiento, Experimentación e Investigaciones Pedagógicas (CPEIP) sets the guidelines and standards for teachers' and principals' professional development, provides leadership and training courses, and also evaluates teachers' performance. For more information, visit https://www.cpeip .cl/ [accessed 21 January 2021].

13 The Agencia de Calidad de la Educación (ACE) designs and implements standardised evaluation tests for students at the national level, and also provides guidelines to schools to improve student achievement. For more information, visit https://www.agenciaeducacion.cl [accessed 21 January 2021].
} 
considers the technological adoption and infrastructure among other aspects, Chile is geographically segregated, and only three out of fifteen regions (the Metropolitan Region of Santiago, Antofagasta, and Magallanes) have achieved a high level of digital readiness (León et al. 2019).

A fourth critical aspect is whether students have adequate space to study. According to a recent survey, the vast majority of students $(67 \%)$ do not have materials at home to complete their homework and tasks, do not have a space to study (63\%), do not have a place in their households where they can concentrate on their school tasks $(80 \%)$, cannot count on an adult at home $(76 \%)$ or a teacher for help (63\%) (Educación2020 2020a).

Considering these unequal structural conditions, it is worth questioning the pertinence of the measures implemented by the Ministry of Education to guarantee the right to education during the pandemic. If students and teachers cannot access the internet smoothly, have no digital equipment and do not necessarily have high digital skills, they may not be able to take advantage of measures which are all online. It is not surprising that only half of the teachers are using the school's texts provided by the Ministry of Education (49\%), and only 27\% use the Ministry's digital platform \#AprendoenCasa (Hinostroza et al. 2020).

\section{Acceptability}

A central aspect of fulfilling the right to education is that students access quality education. In an attempt to ensure quality education and diminish the impact of the pandemic in learning achievements, the Ministry of Education has reduced and prioritised the learning goals and objectives in primary and secondary level curricula (MINEDUC-UCE 2020a, 2020b), and also provided technical-pedagogical strategies to adjust the curriculum for early childhood education (MINEDUC 2020b).

An acceptable education recognises children and adolescents as persons with rights (UNESCO 2019). Therefore, the government and the individuals in charge of children and adolescents must provide conditions which adequately protect their rights (UN 1989). However, during the pandemic, 63\% of students report feeling bored, and $41 \%$ feel anxious or stressed due to the sanitary crisis (Educación2020 2020a). To promote students' well-being, an aspect which the vast majority of teachers consider pivotal today (Elige Educar 2020), the Ministry of Education offers a set of guidelines not only for students and their families, but also for teachers. These guidelines include recommendations for teachers' self-care, video capsules with experts providing key elements for socio-emotional support, online conferences focused on the provision of student support, guidelines to balance academic and household demands, and assistance for the return to schools, among other aspects (MINEDUC-DEG 2020b). The office of the Childhood Secretary has also offered guidelines and recommendations to support and disseminate topics related to the sanitary crisis (MINEDUC 2020b).

The Ministry of Education has made efforts to promote students' physical wellbeing during the pandemic, elaborating protocols to reduce COVID-19 infection in day-care centres, schools and tertiary education institutes, as well as to disseminate 
strategies to prevent and monitor the spread of COVID-19 (MINEDUC-UCE 2020c).

\section{Adaptability}

To guarantee the right to education, the supply of education must be adapted to the specific needs of each student, providing the assistance they require to promote their best interests. This is particularly relevant in the Chilean case, where $5.12 \%$ of students have special educational needs (Holz 2018), and the enrolment of immigrant students has almost quadrupled between 2015 and 2017 (113,585 students) (MINEDUC 2018b). However, during the pandemic, the Ministry of Education has not properly prioritised these groups. It has only provided complementary guidelines for immigrant students and remote teaching strategies for special needs students (MINEDUC-DEG 2020b; 2020c; MINEDUC-SdES 2020).

To sum up, the educational measures implemented by the Chilean government during the pandemic of COVID-19 attempted to make education available, ensuring the provision of online platforms, digital pedagogical resources, and teacher training for online courses. However, the accessibility of these resources could not be granted for every student and teacher due to the high segregation of the educational system and the structural inequality of Chilean society. As in a domino effect, the government measures related to acceptability and adaptability were not universally accessible either. Based on the evidence we have presented above, we have found that the right to education is not being guaranteed for all during the pandemic, partly because the measures adopted by the government do not consider the high segregation of society and the educational system.

\section{Conclusions}

Chile continues to be characterised by a market-oriented educational system, where socio-economic disadvantages are reproduced (García Huidobro 2007; López 2014). The recent educational reform aimed to ensure the right to quality education for all. However, despite its efforts, the right to education in Chile is still not guaranteed for all, because structural inequalities remain intact. The reform eliminated the economic and administrative barriers to access public schools, as well as privileging parental freedom to choose schools, forbidding schools' arbitrary selection processes. Nonetheless, the lack of investment in the provision of public education for all, as well as the lack of adaptability measures, maintain the disadvantages of vulnerable groups (namely immigrant, Indigenous, low socio-economic status and special needs students). Moreover, the educational reform did not address the inefficiency of the high-stakes accountability system (based on standardised tests), maintaining the competition between public schools for high-performing students. Briefly, Chile is still struggling to guarantee two of the four components of the right to education. Without ensuring availability and accessibility to all, achieving acceptability and adaptability may not be possible. 
The measures adopted by the Ministry of Education during the early stages of the COVID-19 pandemic exposed - and to some extent exacerbated - exisiting structural inequalities of the educational system, revealing the impossibility of its transformation without tackling the basis of inequality in Chile. The focus on remote education is not sustainable without universal high-quality connectivity, as well as teachers' and students' complex digital skills. The best interests of every student are not being prioritised, despite the recommendations of the Inter-American Court for Human Rights (IACHR) which compel governments not only to limit or affect human rights (in necessary temporary regulations such as physical distancing etc.) based on scientific criteria, but also to guarantee social, cultural and economic rights especially for the most vulnerable groups, such as children and adolescents (IACHR 2020b). Despite the sanitary crisis, the government must protect and guarantee the normative content of the right to education defined in the different legal instruments. New legislations and programmes should be encouraged in order to progressively guarantee education for all.

A central aspect of human rights is progression. Once certain rights have been achieved, they should not be reversed (Courtis 2018). A great challenge which Chile is facing today, in the context of COVID-19, is to avoid a setback in the right to education, moreover in the context of an economic and social backlash. Considering the legislative progress achieved by the educational reform in establishing the basis for a universal right to quality education, it is still necessary to complement this reform with others that can promote an equal society. Chile's constitutional debate allows us to imagine what type of social contract we need to fulfil the right to education for all, in consonance with others. Re-defining the right to education in the Constitution may restore the Chilean government's responsibilities with regard to education and set the basis for the development of a state which not only guarantees the right to education, but also fulfils it (Cortés and Villalobos 2018).

Acknowledgements This work was funded by the Associative Research Programme - ANID PIA CIE160007.

\section{References}

ACE (Agencia de Calidad de la Educación) (2019). PISA 2018. Entrega de resultados. Competencia Lectora, Matemática y Científica en estudiantes de 15 años en Chile. [Reading, mathematical and scientific competence in 15-year-old students in Chile]. Santiago de Chile: Agencia de Educación. Retrieved 8 January 2021 from http://archivos.agenciaeducacion.cl/PISA_2018_Entrega_de_Resul tados_Chile.pdf.

Bellei, C. (2013). El estudio de la segregación socioeconómica y académica de la educación chilena [The study of socio-economic and academic segregation in Chilean education]. Estudios Pedagógicos, 39(1), 325-345. https://doi.org/10.4067/S0718-07052013000100019.

Bellei, C. (2015). El gran experimento. Mercado y privatización de la educación chilena [The great experiment. Market and privatisation of Chilean education]. Santiago de Chile: Lom Ediciones.

Carrasco, A., Gutiérrez, G., \& Flores, C. (2017). Failed regulations and school composition: Selective admission practices in Chilean primary schools. Journal of Education Policy, 32(5), 642-672. https://doi.org/10.1080/02680939.2017.1312549.

Carrasco, A., \& Honey, N. (2019a). Análisis del impacto del proyecto de admisión justa en las oportunidades educacionales [Analysis of the impact of the fair admission project on educational 
opportunities]. Debates de Justicia Educacional No. 3. Santiago de Chile: Centro de Justicia Educacional. Retrieved 8 January 2021 from https://centrojusticiaeducacional.uc.cl/wp-content/uploa ds/2019/06/debates-n3.pdf.

Carrasco, A., \& Honey, N. (2019b). Nuevo sistema de admisión escolar y su capacidad de atenuar la desigualdad de acceso a colegios de calidad: El inicio de un camino largo [New school admission system and its ability to mitigate unequal access to quality schools: The beginning of a long road]. Estudios en Justicia Educacional No. 1. Santiago de Chile: Centro de Justicia Educacional. Retrieved 8 January 2021 from https://centrojusticiaeducacional.uc.cl/wp-content/uploa ds/2019/09/estudios-n1.pdf.

Carrasco, A., San Martín, E., Bogolaski, F., Flores, C., \& Gutiérrez, G. (2015). "Selección escolar" y desigualdad educacional en Chile: ¿qué tan coactiva es la regulación que la prohíbe? ["School selection" and educational inequality in Chile: How coercive is the regulation that prohibits it?]. Estudios de Política Educativa (MINEDUC), 1(1), 104-157.

CASEN (Encuesta de Caracterización Socioeconómica Nacional) (2017). Resultados encuesta CASEN 2017 [Results of the National Socioeconomic Survey, CASEN 2017] [online database]. Santiago de Chile: Ministerio de Desarrollo Social. Retrieved 8 January 2021 from http://observatorio.minis teriodesarrollosocial.gob.cl/casen-multidimensional/casen/casen_2017.php.

CEPAL (Comisión Económica para América Latina y el Caribe) (2020). América Latina y el Caribe ante la pandemia del COVID-19. Efectos económicos y sociales [Latin America and the Caribbean in the face of the economic and social effects of the COVID-19 pandemic]. Informe Especial No. 1. Santiago de Chile: Economic Commission for Latin America and the Caribbean (CEPAL/ ECLAC). Retrieved 8 January 2021 from https://repositorio.cepal.org/bitstream/handle/11362 /45337/6/S2000264_es.pdf.

CEPAL-OIT (CEPAL-Organización Internacional del Trabajo) (2020). Coyuntura Laboral en América Latina y el Caribe. El trabajo en tiempos de pandemia: Desafios frente a la enfermedad por coronavirus (COVID-19) [Labour market situation in Latin America and the Caribbean. Working in pandemic times: Challenges of coronavirus disease (COVID-19)]. Informe CEPAL/OIT No. 22. Santiago de Chile: Economic Commission for Latin America and the Caribbean (CEPAL/ECLAC) and International Labour Organization (OIT/ILO). Retrieved 8 January 2021 from https://repositori o.cepal.org/bitstream/handle/11362/45557/4/S2000307_es.pdf.

CESCR (UN Committee on Economic, Social and Cultural Rights) (1999). General comment No. 13: The right to education (Art. 13 of the Covenant). Adopted by the Committee on Economic, Social and Cultural Rights at the 21st session, E/C.12/1999/10, 8 December 1999. New York: United Nations Economic ans Social Council (ECOSOC). Retrieved 8 January 2021 from https://docum ents-dds-ny.un.org/doc/UNDOC/GEN/G99/462/16/pdf/G9946216.pdf?OpenElement.

Contreras, M., Corbalán, F., \& Redondo, J. (2007). Cuando la suerte está echada: Estudio cuantitativo de los factores asociados al rendimiento en la PSU [When the die is cast: A quantitative study of factors associated with performance in the PSU (University Selection Test)]. Revista Iberoamericana sobre Calidad, Eficacia y Cambio en Educación, 5(5e), 259-263.

Cortés, A., \& Villalobos, C. (2018). El derecho a la educación en el Chile contemporáneo: Cuatro argumentos para su reconocimiento constitucional [The right to education in contemporary Chile: Four arguments for constitutional recognition]. In J. Gajardo Falcón \& Y. Vásquez Santander (Eds), Nueva constitución: Ideas y propuestas para el cambio constitucional [A new constitution: Ideas and proposals for constitutional change] (pp. 135-154). Santiago de Chile: Rubicón.

Courtis, C. (2018). Derechos económicos, sociales y culturales. Artículo 26. Desarrrollo Progresivo [Economic, social and cultural rights: Article 26, Progressive development]. In Convención Americana sobre Derechos Humanos. Comentario [American Convention on Human Rights: Commentary] (2nd edn, pp. 801-834). Bogotá: Konrad-Adenauer-Siftung.

DEMRE (Departamento de Evaluación, Medición y Registro Educacional) (2018). Proceso de admisión año académico 2011 a 2017: Inscritos y sus puntajes [Admission process academic year 2011 to 2017: Enrollees and their scores]. Santiago de Chile: Unviersidad de Chile, Department of Educational Evaluation, Measurement and Registration (DEMRE).

Donoso, S. (2016). When social movements become a democratizing force: The political impact of the student movement in Chile. Research in Social Movements, Conflicts and Change, 39, 167-196. https://doi.org/10.1108/S0163-786X20160000039008.

Educación2020 (2020a). Informe de resultados \#EstamosConectados: Testimonios y experiencias de las comunidades educativas ante la crisis sanitaria [Results report \#We are connected: Testimonials and experiences of education communities in the face of the health crisis]. Santiago de Chile: 
Fundación Educación 2020. Retrieved 8 January 2021 from http://educacion2020.cl/wp-content/ uploads/2020/04/Informe-Final-Encuesta-EstamosConectados-E2020.pdf.

Educación2020 (2020b). Opinión: Una estrategia nacional de educación pública para un nuevo Chile [Opinion: A national public education strategy for a new Chile]. Santiago de Chile: Fundación Educación 2020. Retrieved 8 January 2021 from http://educacion2020.cl/noticias/opinion-unaestrategia-nacional-de-educacion-publica-para-un-nuevo-chile/.

Elacqua, G., Contreras, D., Salazar, F., \& Santos, H. (2011). The effectiveness of private school franchises in Chile's national voucher program. School Effectiveness and School Improvement, 22(3), 237-263.

Elacqua, G., Montt, P., \& Santos, H. (2013). Evidencias para eliminar - gradualmente - El Financiamiento Compartido [Evidence towards a gradual eliminatation of shared financing]. Claves de Políticas Públicas series, no. 14. Santiago de Chile: Universidad Diego Portales (UDP), Instituto de Políticas Públicas (IPP), Faculdad de Economía y Empresa. Retrieved 8 January 2021 https://study lib.es/doc/5876353/evidencias-para-eliminar-\%E2\%80\%94gradualmente.

Elige Educar (2020). Situación de docentes y educadores en contexto de pandemia. Reporte de resultado. Versión 2 [Situation of teachers and educators in the context of a pandemic: Results report, version 2]. Retrieved 8 January 2021 from https://eligeeducar.cl/content/uploads/2020/09/ee-presentacioncovid-2.pdf.

Falabella, A. (2015). ¿Quién mató la educación pública? Un recuento desde 1979 a 2009 [Who killed public education? A recount from 1979 to 2009]. Cuaderno de Educación, 69, 1-7.

Falabella, A., \& Ramos Zinche, C. (2019). La larga historia de las evaluaciones nacionales a nivel escolar en Chile [The long history of national school-level assessments in Chile]. Cuadernos Chilenos de Historia de La Educación, 11, 66-98.

Flores, C. (2008). Residential segregation and the geography of opportunities: A spatial analysis of heterogeneity and spillovers in education. PhD thesis. Austin, TX: University of Texas at Austin, LBJ School of Public Affairs.

Flores, C., \& Carrasco, A. (2016). Elegir lo que hay: ¿cuentan las familias en sus barrios con una oferta de escuelas que responda a sus preferencias? [Choosing what's available: Do families in their neighborhoods have a choice of schools that meet their preferences?]. In A. Carrasco, J.E GarcíaHuidobro \& J. Corvalán (Eds), Mercado escolar y oportunidad educacional. Libertad, diversidad $y$ desigualdad [School market and educational opportunit:. Freedom, diversity and inequality]. (pp. 17-55). Santiago de Chile: Ediciones UC.

García Huidobro, J.E. (2007). Desigualdad y segmentación del sistema escolar. Consideraciones a partir del caso chileno [Inequality and segmentation of the school system Considerations from the Chilean case]. Revista Pensamiento Educativo, 40(1), 65-85.

Gelber, D., Treviño, E., \& Inostroza, P. (2016). Gender inequality in learning achievement in primary education. What can TERCE tell us? Santiago de Chile: UNESCO. Retrieved 17 January 2021 from http://unesdoc.unesco.org/images/0024/002443/244349e.pdf.

Godoy, F., Salazar, F., \& Treviño, E. (2014). Prácticas de selección en el sistema escolar chileno: Requisitos de postulación y vacíos legales [Selection practices in the Chilean school system: Application requirements and legal loopholes]. Informes para la Política Educativa series, no. 1. Santiago de Chile: Centro de Políticas Comparadas de Educación, Universidad Diego Portales. Retrieved 17 January 2021 from http://cpce.udp.cl/wp-content/uploads/2016/08/IPE1.pdf.

GoC (Government of Chile) (1980). Constitución Política de la República de Chile [Political constitution of the Republic of Chile]. Santiago de Chile: Ministry of the Presidential General Secretariat. Retrieved 8 January 2021 from https://www.bcn.cl/leychile/navegar?idNorma=242302\&idParte=.

GoC (1988). Normas complementarias de administracion financiera, de incidencia presupuestaria y de personal [Complementary rules for financial administration, budget and personnel]. Law 18.768 (1988). Santiago de Chile: Ministry of Finance. Retrieved 8 January 2021 from https://www.bcn.cl/ leychile/navegar?idNorma $=30147$.

GoC (1990). Ley Orgánica Constitucional de Educación [Constitutional Organic Law of Education]. Law 18.962. Santiago de Chile: Ministry of Public Educaition. Retrieved 8 January 2021 from https://www.bcn.cl/leychile/navegar?idNorma=30330.

GoC (1993). Introduce modificaciones a la ley sobre impuesto a la renta; modifica tasa del impuesto al valor agregado; establece beneficio a las donaciones con fines educacionales y modifica otros textos legales que indica [Introduction of modifications to the income tax law; modifying the value added tax rate; establishing benefits for donations for educational purposes and modifying other related legal texts]. Law 19247 (1993). Santiago de Chile: Ministry of Finance. Retrieved 
8 January 2021 from https://www.bcn.cl/leychile/navegar?idNorma=30614\&idParte=86686 13\&idVersion $=$ Diferido.

GoC (2008). Establece ley de subvención escolar preferencial [Establishment of preferential school subsidy law]. Law 20.248 (2008). Santiago de Chile: Ministry of Education. Retrieved 8 January 2021 from https://www.bcn.cl/leychile/navegar?idNorma=269001\&idParte=.

GoC (2009). Establece la ley general de educación [Establishment of a general education law]. Law 20.370 (2009). Santiago de Chile: Ministry of Education. Retrieved 8 January 2021 from https:// www.bcn.cl/leychile/navegar?idNorma $=1006043 \&$ idParte $=$.

GoC (2010a). Fija normas para determinar los alumnos con necesidades educativas especiales que serán beneficiarios de las subvenciones para educación especial [Defining norms to determine which students with special educational needs are eligible for special educational subsidies]. Decree 170 (2010). Santiago de Chile: Ministry of Education. Retrieved 21 January 2021 from http://bcn. cl/2hryq.

GoC (2010b). Establece normas sobre igualdad de oportunidades e inclusión social de personas con discapacidad [Establishment of norms regarding equality of opportunities and social inclusion of disabled persons]. Law 20.422 (2010). Santiago de Chile: Ministry of Planning. Retrieved 21 January 2021 from http://bcn.cl/2f7s1.

GoC (2010c). Fija texto refundido, coordinado y sistematizado de la ley $n^{\circ} 20.370$ con las normas no derogadas del decreto con fuerza de ley $n^{\circ} 1$, de 2005 [Definition of the final wording of Law 20.370, with the unrevoked norms of Decree 1 of 2005]. Decree with Force of Law (DFL) 2 (2010). Santiago de Chile: Ministry of Education. Retrieved 21 January 2021 from http://bcn.cl/2f6yy

GoC (2011). Sistema nacional de aseguramiento de la calidad de la educación parvularia, básica y media y su fiscalización [National system of quality assurance of preschool, basic and secondary education and its supervision]. Law 20.529 (2011). Santiago de Chile: Ministry of Education. Retrieved 8 January 2021 from https://www.bcn.cl/leychile/navegar?idNorma=1028635\&idPar te $=$.

GoC (2015a). De inclusión escolar que regula la admisión de los y las estudiantes, elimina el financiamiento compartido y prohíbe el lucro en establecimientos educacionales que reciben aportes del estado [Inclusive schooling that regulates student admission, eliminates co-funding, and prohibits profit in state-funded educational institutions]. Law 20.845 (2015). Santiago de Chile: Ministry of Education. Retrieved 8 January 2021 from https://www.bcn.cl/leychile/navegar?idNorma=10781 72.

GoC (2015b). Aprueba criterios y orientaciones de adecuación curricular para estudiantes con necesidades educativas especiales de educación parvularia y educación básica [Aproval of curricular adjustment criteria and guidelines for students with special educational needs in kíndergarten and primary school]. Decree 83 (2015). Santiago de Chile: Ministry of Education. Retrieved 21 January 2021 from https://especial.mineduc.cl/wp-content/uploads/sites/31/2016/08/Decreto-83-2015. pdf.

GoC (2015c). Crea las universidades estatales de la región de O'Higgins y de la región de Aysén [Creation of public universities in O’Higgins and Aysen regions]. Law 20.842 (2015). Santiago de Chile: Ministry of Education. Retrieved 21 January 2021 from http://bcn.cl/2mgqp.

GoC (2016a). Crea el sistema de desarrollo profesional docente y modifica otras normas [Creation of the professional teacher development system and modification of other standards]. Law 20.903 (2016). Santiago de Chile: Ministry of Education. Retrieved 8 January 2021 from https://www.bcn.cl/leych ile/navegar?idNorma $=1087343 \&$ idParte $=$.

GoC (2016b). Crea quince Centros de Formación Técnica estatales [Creation of fifteen public vocational institutes]. Law 20.910 (2016). Santiago de Chile: Ministry of Education. Retrieved 21 January 2021 from http://bcn.cl/2ffn2.

GoC (2017). Crea el sistema de educación pública [Creation of a public education system]. Law 21.040 (2017). Santiago de Chile: Ministry of Education. Retrieved 8 January 2021 from https://www.bcn. cl/leychile/navegar?idNorma $=1111237 \&$ idParte $=$.

GoC (2018). Sobre Educación Superior [About tertiary education]. Law 21.091 (2016). Santiago de Chile: Ministry of Education. Retrieved 8 January 2021 from http://bcn.cl/2fcks.

Hinostroza, E., Matamala, C., Ibieta, A., Labbé, C., López, É., Romero, N., González, J., Castillo, D., Claro, M., Jara, Fernández, C., \& Hepp, P. (2020). Docencia durante la crisis sanitaria. La mirada de los docentes. ¿Cómo están abordando la educación remota los docentes de las escuelas y liceos de Chile en el contexto de la crisis sanitaria? [Teaching during the health crisis: How are teachers in Chilean schools and high schools addressing remote education in the context of the health 
crisis?]. Santiago de Chile: Instituto de Informática Educativa de la Universidad de La Frontera et al. Retrieved 8 January 2021 from http://miradadocentes.cl/Informe-de-Resultados_Docencia_ Crisis_Sanitaria.pdf.

Hofflinger, Á., Gelber, D., \& Tellez Cañas, S. (2020). School choice and parents' preferences for school attributes in Chile. Economics of Education Review, 74. Art. 101946. https://doi.org/10.1016/j. econedurev.2019.101946.

Holz, M. (2018). Datos de la modalidad de Educación Especial en Chile, año 2018 [Data on the modality of special education in Chile, 2018]. Biblioteca del Congreso Nacional de Chile. Asesoría Técnica Parlamentaria, Diciembre. Santiago de Chile: Biblioteca del Congreso Nacional de Chile (BCN). Retrieved 8 January 2021 from https://obtienearchivo.bcn.cl/obtienearchivo?id=repositori o/10221/26781/2/BCN_datos_de_EE_y_estudiantes_con_NEE_Final.pdf

Holz, M., \& Castro Paredes, L. (2014). Financiamiento compartido. Análisis de los datos oficiales [Shared financing: Analysis of official data]. Santiago de Chile: Biblioteca del Congreso Nacional de Chile (BCN). Retrieved 8 January 2021 from: https://obtienearchivo.bcn.cl/obtie nearchivo?id=repositorio/10221/20694/1/BCN_Financiamiento\%20Compartido_ANALISIS $\% 20$ DE\%20DATOS_Final_v3.pdf.

IACHR (Inter-American Court of Human Rights) (2020a). Caso Gonzales Lluy y otros Vs. Ecuador. Excepciones Preliminares, Fondo, Reparaciones y Costas. Sentencia de 1 de septiembre de 2015. Serie C No. 298 (No. 22; pp. 133-134) [The case of Gonzales Lluy et al. vs. Ecuador. Preliminary objections, merits, reparations and costs. Ruling of 1 September 2015]. San José: Corte IDH/ IACHR. Retrieved 8 January 2021 from http://www.corteidh.or.cr/sitios/libros/todos/docs/cuade rnillo22.pdf.

IACHR (2020b). COVID-19 y derechos humanos: Los problemas y desafios deben ser abordados con perspectiva de derechos humanos y respetando las obligaciones internacionales. Declaración de la Corte Interamericana De Derechos Humanos 1/20. [COVID-19 and human rights: Problems and challenges must be addressed from a human rights perspective and with respect for international obligations. Declaration 1/20 of the Inter-American Court of Human Rights]. San Josè: IACHR. Retrieved 8 January 2021 from http://www.corteidh.or.cr/tablas/alerta/comunicado/declaracio n_1_20_ESP.pdf.

ILO (International Labour Organization) (2020). COVID-19 and the world of work: Impact and responses. ILO Monitor No. 1. Geneva: OIT/ILO. Retrieved 8 January 2021 from https://www. ilo.org/wcmsp5/groups/public/—dgreports/—dcomm/documents/briefingnote/wcms_738753.pdf .

ILO \& ECLAC (ILO \& Economic Commission for Latin America and the Caribbean). (2020). The COVID-19 pandemic could increase child labour in Latin America and the Caribbean. Technical Note No. 1. Santiago de Chile: ILO \& CEPAL/ECLAC. Retrieved 8 January 2021 from https ://www.ilo.org/wcmsp5/groups/public/_americas/_ro-lima/documents/publication/wcms_74766 2.pdf.

ILO \& UNICEF (ILO \& United Nations Children's Fund). (2020). COVID-19 and child labour: A time of crisis, a time to act. New York: ILO-UNICEF.

Larrañaga, O., Cabezas, G., \& Dussaillant, F. (2014). Trayectorias educacionales e inserción laboral en la enseñanza media técnico professional [Educational trajectories and labour insertion in technical and professional secondary education]. Estudios Públicos, 134, 7-58.

León, R, \& Meza, S. (2018). Brecha en el uso de internet: Una expresión de la exclusión social [Gap in internet use: An expression of social exclusion]. Santiago de Chile: Fundación País Digital. Retrieved 8 January 2021 from https://paisdigital.org/brecha-en-el-uso-de-internet-una-expresionde-la-exclusion-social/.

León, R., Meza, S., \& Araneda, T. (2019). Digital readiness Chile. Santiago de Chile: Fundación País Digital \& CISCO USA. Retrieved 8 January 2021 from https://s3.amazonaws.com/paisdigital/wpcontent/uploads/2020/03/30173007/Digital-Readiness-Chile-espa\%C3\%B1ol-online.pdf.

López, N. (2014). Mercado o garantía de derechos. Modelos en debate para la educación escolar en Chile [Market or guarantee of rights. Models under discussion for school education in Chile]. Buenos Aires: UNESCO-IIEP \& UNICEF. Retrieved 8 January 2021 from https://unesdoc.unesco.org/ ark:/48223/pf0000231306.

Meneses, A., Gallegos, F., Claro, M., Murillo, F., \& Sotomayor, C. (2020). Didácticas para la proximidad: Aprendiendo en tiempos de crisis [Didactics for proximity: Learning in times of crisis]. Santiago de Chile: PUC-Universidad de Chile. Retrieved 8 January 2021 from https://www.pucv.cl/ uuaa/instituto-de-quimica/noticias/didacticas-para-la-proximidad-aprendiendo-en-tiempos-de-crisi s/2020-07-23/181922.html. 
MINEDUC (Ministerio de Educación) (2018a). Indicadores de la educación en Chile 2010-2016 [Education indicators in Chile 2010-2016]. Santiago de Chile: Ministry of Education (MINEDUC). Retrieved 8 January 2021 from https://centroestudios.mineduc.cl/wp-content/uploads/sites /100/2018/03/INDICADORES_baja.pdf.

MINEDUC (2018b). Política Nacional de Estudiantes Extranjeros 2018-2022 [National policy on foreign students 2018-2022] (pp. 1-30). Santiago de Chile: Ministry of Education. Retrieved 8 January 2021 from https://migrantes.mineduc.cl/wp-content/uploads/sites/88/2020/04/Pol\%C3\%ADtic a-Nacional-Estud-Extranjeros.pdf.

MINEDUC (2019). Cargos Docentes años 2003 al 2019 [Teaching positions years 2003 to 2019] [online database]. Santiago de Chile: Ministry of Education. Retrieved 8 January 2021 from http://datos .mineduc.cl/dashboards/20031/descarga-bases-de-datos-de-cargos-docentes/.

MINEDUC (2020a). Orientaciones generales para guíar el aprendizaje de los estudiantes a distancia en instituciones de Educación Superior [General distance learning guidelines for students in higher education institutions]. Santiago de Chile: Ministry of Education. Retrieved 8 January 2021 from https://educacionsuperior.mineduc.cl/wp-content/uploads/sites/49/2020/05/PLAN-DE-ACCIO N-COVID-19.pdf.

MINEDUC (2020b). Orientaciones MINEDUC Covid-19 [COVID-19 guidelines from the Ministry of Education]. Santiago de Chile: Ministry of Education. Retrieved 8 January 2021 from MINEDUC website: https://www.mineduc.cl/orientaciones-mineduc-covid-19/.

MINEDUC (2021). Solo el 15\% de los colegios que volvieron a clases presenciales tuvo algún caso de Covid [Only 15\% of schools that returned to in-person classes had at least one COVID case] [webnews item, 15 January]. Santiago de Chile: Ministry of Education. Retrieved 20 January 2021 from https://www.mineduc.cl/el-15-de-los-colegios-con-clases-presenciales-tuvo-algun-caso-de-covid/.

MINEDUC-DEG (MINEDUC-División de Educación General) (2020a). Orientación al sistema escolar en contexto de COVID-19 [Guidelines for the school system in the context of COVID-19]. Santiago de Chile: MINEDUC \& General Education Division (DEG). Retrieved from https://migrantes. mineduc.cl/2020/03/30/orientacion-al-sistema-escolar-en-contexto-de-covid-19/.

MINEDUC-DEG (2020b). Orientación al sistema escolar en contexto de COVID-19. Escuelas especiales $y$ cursos especiales de establecimientos educacionales con PIE [Guidelines for the school system in the context of COVID-19: Special schools and special courses of educational establishments with PIE]. Santiago de Chile: MINEDUC \& General Education Division (DEG). Retrieved 8 January 2021 from https://www.mineduc.cl/wp-content/uploads/sites/19/2020/03/OrientacionesContext oCOVID19_2703.pdf.

MINEDUC-DEG (2020c). Orientaciones complementarias por COVID-19. Comunidades educativas inclusivas, estudiantes extranjeros y sus familias [Complementary guidance for COVID-19: Inclusive educational communities, foreign students and their families]. Santiago de Chile: MINEDUC \& General Education Division (DEG). Retrieved 8 January 2021 from https://migrantes.mined uc.cl/2020/04/07/orientaciones-complementarias-por-covid19-ept/.

MINEDUC-SdES (MINEDUC-Subsecretaría de Educación Superior) (2020). Plan de acción MINEDUC para Instituciones de Educación Superior [Ministry of Education action plan for higher education institutions]. In Mineduc Acuerda Alianza de Cooperación Internacional Para Apoyar Con Recursos Digitales y Capacitaciones a Docentes de Educación Superior [Ministry of Education agrees to international cooperation alliance to support higher education teachers with digital resources and training] [webnews item, 22 April]. Santiago de Chile: Ministry of Education, Subsecretariat of Higher Education (SdES). Retrieved 8 January 2021 from https://educacionsuperior.mined uc.cl/2020/04/22/mineduc-acuerda-alianza-de-cooperacion-internacional-para-apoyar-con-recur sos-digitales-y-capacitaciones-a-docentes-de-educacion-superior/.

MINEDUC-UCE (MINEDUC-Unidad de Currículum y Evaluación) (2020a). Fundamentación priorización curricular COVID-19. Para el Consejo Nacional de Educación [Foundation of curricular prioritisation COVID-19: For the National Council of Education]. Santiago de Chile: Ministry of Education. Retrieved from MINEDUC website: https://curriculumnacional.mineduc.cl/614/artic les-179650_archivo_01.pdf.

MINEDUC-UCE (2020b). Orientaciones y priorización curricular [Guidelines and curricular prioritisation] [dedicated website]. Santiago de Chile: MINEDUC \& Curriculum and Evaluation Unit (UCE). Retrieved 8 January 2021 from https://curriculumnacional.mineduc.cl/614/articles-17804 2_recurso_1.pdf.

MINEDUC-UCE (2020c). Priorización curricular COVID-19 Educación Parvularia. Sala Cuna, Nivel Medio y Nivel Transición [Curricular prioritisation COVID-19 Early Childhood Education: 
Nursery school, middle and transition levels]. Santiago de Chile: Ministry of Education \& Curriculum and Evaluation Unit (UCE). Retrieved 8 January 2021 from https://curriculumnacional.mined uc.cl/614/articles-177754_archivo_01.pdf.

Mizala, A., \& Torche, F. (2012). Bringing the schools back in: The stratification of educational achievement in the Chilean voucher system. International Journal of Educational Development, 32(1), 132-144. http://dx.doi.org/10.1016/j.ijedudev.2010.09.004.

Montecinos, C., Uribe, M., \& Volante, P. (2020). Liderazgo escolar: Aprendiento en tiempos de crsis. Conectar, colaborar, contener, capacitar y confiar [School leadership: Learning in a time of crisis. Connecting, collaborating, containing, empowering and trusting]. Santiago de Chile: PUC-Universidad de Chile.

MTT (Ministerio de Transportes y Telecomunicaciones). (2020). Plan Solidario de Conectividad [Solidary plan for connectivity]. Santiago de Chile: Ministry of Transport and Telecommunications.

MTT-MINEDUC (2020). Conectividad para la Educación 2030 [Connectivity for Education project] [dedicated project webage]. Santiago de Chile: Ministry of Transport and Telecommunications and Ministry of Education. https://www.innovacion.mineduc.cl/iniciativas/cpe2030.

OECD (Organisation for Economic Co-operation and Development). (2010). PISA 2009 results: Overcoming social background. Equity in learning opportunities and outcomes. Paris: OECD.. https:// doi.org/10.1787/9789264091504-en.

OECD. (2016). PISA 2015 results: Excellence and equity in education. Paris: OECD. https://doi. org/10.1787/9789264266490-en.

OECD (2019a). Education at a glance 2019: OECD Indicators. Country Note Chile. Paris: OECD. Retrieved 8 January 2021 from https://www.oecd.org/education/education-at-a-glance/EAG20 19_CN_CHL.pdf

OECD (2019b). TALIS 2018 results (volume I): Teachers and school leaders as lifelong learners. Teaching and Learning International Survey (TALIS). Paris: OECD. https://doi.org/10.1787/1d0bc $92 \mathrm{a}-\mathrm{en}$

OECD. (2020). OECD Economic outlook, June 2020. Paris: OECD. https://doi.org/10.1787/0d1d1 e2e-en.

Quaresma, M.L. (2017). Excellence in high-performing public schools in Chile. Students' perceptions and experiences. Schools: Studies in Education, 14(1), 28-53. https://doi.org/10.1086/691250.

Quiroz Reyes, C. (2020). Pandemia Covid-19 e inequidad territorial: El agravamiento de las desigualdades educativas en Chile [Pandemic Covid-19 and territorial inequity: The worsening of educational inequalities in Chile]. Revista Internacional de Educación Para La Justicia Social, 9(3e), $1-6$.

Reimers, F., \& Schleicher, A. (2020a). A framework to guide an education response to the COVID-19 Pandemic of 2020. Paris: OECD. Retrieved 8 January 2021 from https://globaled.gse.harvard.edu/ files/geii/files/framework_guide_v2.pdf.

Reimers, F., \& Schleicher, A. (2020b). Schooling disrupted, schooling rethought. How the COVID-19 pandemic is changing education. Preliminary version. Paris: OECD. Retrieved 8 January 2021 from https://www.gcedclearinghouse.org/resources/schooling-disrupted-schooling-rethought-howcovid-19-pandemic-changing-education?language=en.

Rosas, R., \& Santa Cruz, C. (2013). Dime en qué colegio estudiaste y te diré que CI tienes: Radiografía al desigual acceso al capital cognitivo en Chile [Tell me which school you attended and I'll tell you what your IQ is: An X-ray of unequal access to cognitive capital in Chile]. Santiago de Chile: Ediciones UC.

Sanz, I., Sáinz González, J., \& Capilla, A. (2020). Efectos de la crisis del Coronavirus en la educación [Effects of the Coronavirus crisis on education]. Informe No. 7. Madrid: Organización de Estados Iberoamericanos para la Educación, la Ciencia y la Cultura (OEI). Retrieved 8 January 2021 from https://www.flacsi.net/wp-content/uploads/2020/04/EFECTOS-DE-LA-CRISIS-DEL-CORON AVIRUS-EN-EDUCACI\%C3\%93N.pdf.

Strauss, A. L., \& Corbin, J. M. (2002). Bases de la investigación cualitativa: Técnicas y procedimientos para desarrollar la teoría fundada (I) [Bases of qualitative research: Techniques and procedures for developing grounded theory (I)]. Medellín: Universidad de Antioquia, Facultad de Enfermería.

Tomasevski, K. (2004). Manual on rights-based education: Global human rights requirements made simple. Bangkok: UNESCO. Retrieved 8 January 2021 from https://unesdoc.unesco.org/ark:/48223/ pf0000135168.

Torche, F. (2005). Privatization reform and inequality of education opportunity: The case of Chile. Sociology of Education, 78(4), 316-343. https://doi.org/10.1177/003804070507800403. 
Treviño, E. (2018). Diagnóstico del Sistema Escolar: Las reformas educativas 2014-2017 [Diagnosis of the school system: Education reforms 2014-2017]. In I. Sánchez Diaz (Ed.), Ideas en educación II. Definiciones en tiempos de cambio [Ideas in education II: Definitions in times of change]. Santiago de Chile: Ediciones UC.

Treviño, E., Carrasco, A., Villalobos, C., \& Morel, M. J. (2019). Financiamiento de la educación escolar en Chile: La reforma estructural pendiente [Financing school education in Chile: The pending structural reform]. In A. Carrasco \& L. M. Flores (Eds.), De la reforma a la transformación: Capacidades, innovaciones, y regulación de la educación chilena [From reform to transformation: Capacities, innovations and regulation in Chilean education] (pp. 505-544). Santiago de Chile: Ediciones UC.

Treviño, E., Mintrop, R., Villalobos, C., \& Órdenes, M. (2018). What might happen if school vouchers and privatization of schools were to become universal in the U.S.: Learning from a national test case - Chile. Boulder, CO: National Education Policy Center. Retrieved 17 January 2021 from https://nepc.colorado.edu/sites/default/files/publications/PB\%20Trevino-Mintrop_0.pdf.

Treviño, E., Villalobos, C., Morel, M. J., \& Carrasco, A. (2020). Financiamiento de la educación pública. Hacia la construcción de nuevo trato [Financing public education: Towards the construction of a new deal]. In C. Adlerstein et al., Horizontes y propuestas para transformar el sistema educativo chileno [Outlook and proposals for transforming the Chilean education system] (pp. 300-323). Santiago de Chile: Biblioteca del Congreso Nacional de Chile.

UN (United Nations) (1966). International covenant on economic, social and cultural rights. New York: United Nations. Retrieved 8 January 2021 from https://www.ohchr.org/Documents/Profe ssionalInterest/cescr.pdf.

UN (1989). Convention on the rights of the child. General Assembly resolution 44/25. New York: UN. Retrieved 8 January 2021 from https://www.ohchr.org/EN/ProfessionalInterest/Pages/CRC. aspx.

UN (2020). The impact of COVID-19 on children. Policy brief, 15 April. New York: United Nations. Retrieved 8 January 2021 from https://www.un.org/sites/un2.un.org/files/policy_brief_on_covid impact_on_children_16_april_2020.pdf.

UNDP (United Nations Development Programme) (2017). Desiguales. Orígenes, cambios y desafíos de la brecha social en Chile [Unequal: Origins, changes and challenges of the social gap in Chile]. Santiago de Chile: Programa de las Naciones Unidas para el Desarrollo (PNUD/UNDP). Retrieved 8 January 2021 from https://www.undp.org/content/dam/chile/docs/pobreza/undp_cl_ pobreza-Libro-DESIGUALES-final.pdf.

UNDP (2020). COVID-19 and human development: Assessing the crisis, envisioning the recovery. New York: UNDP. Retrieved 8 January 2021 from http://hdr.undp.org/en/hdp-covid.

UNESCO (United Nations Educational Scientific and Cultural Organization) (2019). Right to education handbook. Paris: UNESCO. Retrieved 8 January 2021 from https://unesdoc.unesco.org/ ark:/48223/pf0000366556.

UNICEF (United Nations Children's Fund) (2007). A human rights-based approach to Education for All: A framework for the realization of children's right to education and rights within education. New York: UNICEF. Retrieved 8 January 2021 from https://unesdoc.unesco.org/ark:/48223/ pf0000154861.

Valenzuela, J. P. (2008). Segregación en el Sistema Escolar Chileno: En la búsqueda de una educación de calidad en un contexto de extrema desigualdad [Segregation in the Chilean School System: In search of quality education in a context of extreme inequality]. Transformaciones del Espacio Público: II Escuela Chile-Francia [Transformations of public space: The second Chile-France School] (pp. 131-156). Santiago de Chile: Universidad de Chile.

Valenzuela, J. P., Bellei, C., \& De los Ríos, D. (2010). Segregación escolar en Chile [School segregation in Chile]. In S. Martinic \& G. Elacqua (Eds), ¿Fin de ciclo? Cambios en la gobernanza del sistema educativo [The end of the cycle? Changes in the governance of the education system]. (pp. 209-229). Retrieved 8 January 2021 from https://unesdoc.unesco.org/ark:/48223/pf000 0190544.

Valenzuela, J. P., Bellei, C., \& De los Ríos, D. (2014). Socio-economic school segregation in a marketoriented educational system: The case of Chile. Journal of Educational Policy, 29(2), 217-241. https://doi.org/10.1080/02680939.2013.806995.

World Bank (2020). Global economic prospects. A flagship report. Washington, DC: International Bank for Reconstruction and Development/The World Bank. Retrieved 8 January 2021 from https:// openknowledge.worldbank.org/handle/10986/33748. 
Yoo, T., de Wysocki, M., \& Cumberland, M. (2018). Country digital readiness: Research to determine a country's digital readiness and key interventions. San Jose, CA: Cisco. Retrieved 8 January 2021 from https://www.cisco.com/c/dam/assets/csr/pdf/Country-Digital-Readiness-White-Paper-US.pdf.

Publisher's Note Springer Nature remains neutral with regard to jurisdictional claims in published maps and institutional affiliations.

Denisse Gelber PhD (University of Texas, Austin), is a researcher at the Centre of Advanced Studies on Educational Justice at the Pontifical Catholic University of Chile, in Santiago, Chile. For the last 15 years she has specialised in education, poverty and social mobility, with an increasing focus on pedagogical practices and inclusion.

Carolina Castillo is an anthropologist (University of Chile) with a Master's degree in sociology (University of Barcelona). She is currently a researcher at the Centre of Advanced Studies on Educational Justice at the Pontifical Catholic University of Chile, in Santiago, Chile.

Luciano Alarcón is a lawyer (University of Chile) and is currently taking two diplomas in Human Rights and Public Law (University of Chile).

Ernesto Treviño $\mathrm{PhD}$ (Harvard University), is the principal researcher of the "Pedagogical inclusion" unit at the Centre of Advanced Studies on Educational Justice, and is also the director of the Centre for Educational Transformation at the Pontifical Catholic University in Chile.

Rosario Escribano $\mathrm{PhD}$ (Pontifical Catholic University of Chile), is a researcher at the Centre of Advanced Studies on Educational Justice at the Pontifical Catholic University of Chile, in Santiago, Chile. She specialises in quantitative analysis, classroom observations, quality of pedagogical practices, and teacher evaluation.

\section{Authors and Affiliations}

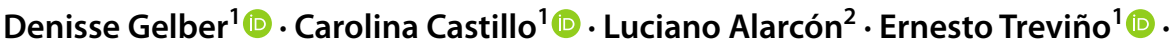 Rosario Escribano ${ }^{1}$ (1)}

Carolina Castillo

carolina.castillo@uc.cl

Luciano Alarcón

lucianoalarconflores@gmail.com

Ernesto Treviño

ernesto.trevino@uc.cl

Rosario Escribano

mdescrib@uc.cl

1 Centre of Advanced Studies on Educational Justice, Pontifical Catholic University of Chile, Santiago, Chile

2 Human Rights Programme, University of Chile, Santiago, Chile 